\title{
The Contact Hypothesis and Millennial Evangelical Protestants' Attitudes toward Same-Sex Families
}

\author{
Elisha Marr, PhD \\ Calvin College
}

* Please address correspondence to Elisha Marr, Calvin College, Sociology and Social Work Department, 3201 Burton Street SE, Grand Rapids, MI 49546. Email: emm24@calvin.edu.

\begin{abstract}
Research regarding attitudes towards same-sex couples and their creation of families has identified a few trends including: 1) Millennials are the generation most likely to have favorable views of same-sex families, 2) evangelical Protestants are the religious group least likely to be supportive, and 3) people who have contact with lesbian women, gay men, bisexual, and queer identified people $(L G B Q)$ are more likely to support their coupling and family creation. Millennial evangelical Protestants (MEP) were surveyed about their attitudes towards same-sex headed families to learn whether their attitudes were more consistent with their age or religious affiliation and whether contact with $L G B Q$ people had any influence on their opinions. It was found that although there are a portion of MEPs who feel positively about same-sex families, a notable and often larger portion consider same-sex relationships to be wrong and are not supportive of legislation that promotes same-sex families. However, it was also found that contact with $L G B Q$ individuals increased favorable attitudes toward same-sex families, and knowing someone in a same-sex relationship has a greater impact on attitudes than only knowing someone who is $L G B Q$. These findings have important implications for the future of MEPs' relationships with the church.
\end{abstract}

Keywords: same-sex, gay, family, evangelical, millennial, contact

Within the past decade, there has been an upsurge in support for what are commonly known as LGBT (lesbian, gay, bisexual, transgender) family rights in the United States, including but not limited to allowing same-sex couples to marry and adopt children legally (Jones, Cox, and Navarro-Rivera 2014). In 2004, a little less than one-third of survey respondents in the U.S. supported same-sex marriage (31\%, Pew Research Center 2014c). By 2014, more than half favored it (54\%, Pew Research Center 2014c). Support for laws and policies that permit 
same-sex couples to create families through marriage or adoption is more likely among Millennials (those born after 1980), those who have attended or graduated from college, Jewish Americans, and those who have contact with someone who is LGBT (Jones, Cox, and Navarro-Rivera 2014). Comparatively, the Silent Generation (those born before 1946), those who have not attended college (high school diploma or less), evangelical Protestants, and those who do not have a close friend or family member who is LGBT are less likely to approve (Jones, Cox, and Navarro-Rivera 2014).

The central focus of this study is the attitudes of young evangelicals who may be more supportive of same-sex relationships ${ }^{1}$ based on their age, yet less supportive based on their religious affiliation. Additionally, the project examined the extent to which contact with $\mathrm{LGBQ}^{2}$ people has an effect on participants' attitudes towards same-sex couples creating families. This study helps us learn about the sexuality attitudes of this new generation of evangelical Protestant adults and how they are affected by contact with LGBQ people. The study provides insight into the future of Millennials' relationship with the evangelical Protestant tradition, gauging whether the tradition is likely to grow in support of or opposition to families headed by same-sex couples.

\section{Background}

To provide context for this project, literature on attitudes towards samesex relationships among Millennials and evangelical Protestants is reviewed first, followed by a summary of relevant research on the contact hypothesis and influence on attitudes. This section concludes with an outline of the existing information available on Millennial evangelical Protestants' attitudes toward same-sex relationships and an explanation of how this study contributes to the scholarship on these topics.

\section{Millennials}

Millennials are the youngest generation of adults and are often compared with Generation X (born 1965 - 1979), Baby Boomers (born 1946 - 1964), and

\footnotetext{
${ }^{1}$ Research on same-sex relationships has involved learning about attitudes towards individuals (e.g., homosexuals, gay men, lesbian women), same-sex marriage, civil unions, same-sex couples adopting children, workplace discrimination, and hate crimes. These topics are often lumped under the phrase "LGBT rights". However, this article focuses on lesbian, gay, bisexual, and queer couples creating families through marriage and/or adoption and does not include topics such as workplace discrimination or hate crimes. When not specifically referring to work done by others, the author will commonly use the terms samesex relationships and same-sex-headed family creation.

${ }^{2}$ In order to avoid conflating sexuality with gender, and recognizing that attitudes towards sexuality are different than attitudes toward gender, the concepts used in this article will be limited to lesbian, gay, bisexual, and queer. Thus, when not specifically referring citing the work of others, the acronym LGBQ will be used (omitting the $\mathrm{T}$ for transgender). 
the Silent Generation (born before 1946). It has been found that Millennials have similar opinions to older generations regarding certain social issues such as abortion and gun control, yet are more liberal in their attitudes towards interracial marriage, marijuana legalization, and same-sex marriage (Pew Research Center 2014b).

Scholars attempting to explain the swift change in attitudes toward samesex relationships often credit favorable attitudes among Millennials as the explanatory factor. They note that, as the younger Millennial cohort replaces the older cohorts, the population is overall more likely to support LGBQ rights (Baunauch 2011). A 2013 survey found that 70 percent of Millennials support same-sex marriage; at that time, Millenials comprised 27 percent of the adult population. This finding marked a considerable increase from 2003, when only 51 percent of Millennials supported same-sex marriage and they comprised nine percent of the population (Dimock, Doherty, and Kiley 2013). N. Silver's (2013) analysis of eight national opinion polls notes that the steady increase in support for same-sex marriage is consistent with the idea that younger Americans are replacing older ones in the electorate. It is estimated that about half of the increase in support is attributed to this generational turnover (Silver 2013). D.M. Baunach (2011) explicitly investigated whether cohort replacement explained attitude change towards gay marriage in the U.S. by analyzing data from multiple years of the General Social Survey. Cohort succession was determined to be responsible for one-third of the change (Baunauch 2011).

M. Dimock, C. Doherty, and J. Kiley (2013) note that attitude change regarding same-sex relationships is occurring among older generations as well. The Silent Generation's support for same-sex marriage increased from 17 percent in 2003 to 31 percent in 2013 (14\% increase). Baby Boomers exhibited the lowest portion of growth from 33 percent in 2003 to 38 percent in 2013, and Generation $\mathrm{X}$ moved from 41 to 49 percent (i.e., increases of $5 \%$ and $8 \%$ respectively). Yet the greatest increase in support for same-sex marriage occurred among the Millennial generation, whose jump from 51 to 70 percent was a 19 point increase (Dimock, Doherty, and Kiley 2013). The combination of these attitude changes within each generation indicates that not all of the growth in support for same-sex marriage can be explained by cohort replacement. In fact, Baunach's work identified attitudinal change as the explanatory factor accounting for two-thirds of the increase in support for gay marriage (Baunauch 2011).

Although much research on same-sex relationships focuses on same-sex marriage, attitudes toward other aspects of same-sex-headed family creation have also been explored. For instance, in 2013, two-thirds of Americans agreed that gay and lesbian couples could be as good as heterosexual couples as parents (68\%). Millennials were the generation most likely to agree (79\%), almost 30 percentage points greater than the Silent Generation (50\%; Jones, Cox, and Navarro-Rivera 2014). Almost 60 percent of Americans approved of gay and lesbian couples adopting children (58\%). Support among the generational groups was consistent with previously identified trends, with 70 percent of Millennials, 58 percent of Generation Xers, 52 percent of Baby Boomers, and 42 percent of 
the Silent Generation favoring LGBQ persons adopting (Jones, Cox, and NavarroRivera 2014).

\section{Evangelical Protestants}

Evangelical Protestantism is one among many U.S. religious traditions. Evangelical Protestant denominations are distinguished as being more theologically and socially conservative than mainline Protestantism (The Association of Religion Data Archives 2010). Evangelicals are also known for greater separation from the broader culture and stricter adherence to religious traditions (Streensland, Park, Regnerus, Robinson, Wilcox, and Woodberry 2000). Evangelicals are more likely than other religious groups to identify religion as the factor that most influences their thinking about government and public affairs (Smidt 2013, 186). As of 2007, evangelical Protestantism was the largest religious tradition in the U.S., with 26.3 percent of Americans indicating affiliation (Smidt 2013, 70).

Research on the sexuality attitudes of evangelical Protestants indicates that they are the tradition least supportive of same-sex relationships (Jones, Cox, and Navarro-Rivera 2014; Rowatt, LaBouff, Johnson, Froese, and Tsang 2009). An analysis of the 2007 Pew Forum Religious Landscape Survey showed that less than one-third of evangelical Protestants (28\%) agreed that "homosexuality is a way of life that should be accepted by society," compared to 58 percent of mainline Protestants and 62 percent of Roman Catholics (Smidt 2013, 188). Results from the 2007 Baylor Religion Survey revealed that mainline Protestants, Catholics, "other" religious groups, and the religiously unaffiliated are more likely to support same-sex marriage than evangelical Protestants. Among evangelical Protestants, the question of same-sex marriage "elicits a strong, unfavorable view regardless of their views toward the cause of homosexuality," (Whitehead 2010, 74).

The Pew Center's more recent survey on LGBT Issues and Trends (2014) included racial distinctions in religious affiliation. Most of the religious affiliations demonstrated majority support for same-sex marriage (e.g., Hispanic Catholic 56\%, White Catholic 58\%, White mainline Protestant 62\%, Jewish $83 \%$ ). White evangelical Protestants were among the three religious affiliations in which less than half of the participants supported same-sex marriage (White evangelical Protestants 27\%, Black Protestants 35\%, Hispanic Protestants 46\%; Jones, Cox, and Navarro-Rivera 2014). This survey included questions regarding additional aspects of same-sex-headed family creation. The results showed that, with the exception of White evangelical Protestants, the majority of religious respondents agreed that gay and lesbian couples can be as good as heterosexual couples as parents. White evangelical Protestants, along with Hispanic and Black Protestants, are also the religious traditions in which less than 50 percent support allowing gay and lesbian couples to adopt children (33\%, 46\%, and $40 \%$ respectively; Jones, Cox, and Navarro-Rivera 2014).

These increasingly tolerant attitudes among people in certain religious traditions towards same-sex relationships is evident in some of the trends of associated religious institutions. In July 2015, a few days after the U.S. Supreme 
Court legalized same-sex marriage nationwide, the Pew Research Center outlined the standings of major religious traditions (Masci and Lipka 2015). They note that the Conservative and Reformed Jewish movements had approved of same-sex marriage for a number of years. Some Mainline Protestant denominations, such as the Episcopal Church and the Presbyterian Church (U.S.A), recently sanctioned blessings or same-sex marriage ceremonies. However; most religious institutions have remained firmly against allowing same-sex marriages. These include the Roman Catholic Church, the Orthodox Jewish movement, the Southern Baptist Convention, and other evangelical Protestant denominations (Masci and Lipka 2015).

\section{The Contact Hypothesis and Influence on Attitudes}

The contact hypothesis posits that intergroup contact can increase tolerance and empathy while decreasing stereotypes, prejudice, and conflict. Since its inception in the early 1950s, researchers have found factors and situations within which contact with previously unfamiliar groups has had an impact on related attitudes (Dovidio, Glick, and Rudman 2005). Scholars have demonstrated that contact between different individuals can favorably impact intergroup relationships in regards to race (Amir 1998), age (Caspi 1984), and religion (Putnam and Campbell 2010, 526-529). For example, D.P. Green and J.S. Wong (2009) used an Outward Bound multiple week wilderness course as the setting for a randomized field experiment. They found that a month after completing the course, students in the racially diverse group expressed greater levels of racial tolerance and reduced racially aversive attitudes in comparison to the racially homogeneous control group (Green and Wong 2009).

The contact hypothesis has also been employed by researchers to explain attitudes towards LGBQ people. G.M. Herek and J.P. Capitanio (1996) found that heterosexuals who had contact with gay men or lesbian women reported more favorable attitudes towards same-sex attracted people. Additionally, heterosexuals with more intimate or multiple contacts with gay or lesbian people indicated higher rates of favorability than those with little or no contact (Herek and Capitanio 1996). G.G. Lewis' (2011) meta-analysis of 27 nationally representative survey results revealed that respondents who knew someone gay, lesbian, or bisexual were more likely to support gay rights, a trend identified in every demographic, religious, and political group (Lewis 2011). Dimock, Doherty, and Kiley (2013) specifically sought to learn about the factors contributing to attitudinal change towards same-sex marriage. In a 2013 survey, it was determined that one-in-seven people have changed their mind to support gay marriage. When respondents who reported having changed their mind were asked why their views changed, the most common answer was contact with a person who is homosexual (32\%; Dimock, Doherty, and Kiley 2013). J. Barth and J. Parry (2009) expanded on this line of research by testing whether knowing someone in a same-sex romantic relationship had greater impact on attitudes than simply knowing someone who identified as gay or lesbian. They concluded that knowing same-sex couples had a distinct impact on attitudes towards legal recognition of same-sex partnerships; however, knowing a lesbian or gay man, 
whether in couples or not, was a stronger predictor of support in regard to other policies (e.g., nondiscrimination laws, adoption of children by lesbians and gay men; Barth and Parry 2009).

The contact hypothesis has not been found to be effective in every heterogeneous interaction and situation. The research regarding religion and attitudes towards LGBQ relationships and families reveals the complex effects that multiple factors can have on attitudes. S.A. Skipworth, A. Garner, and B.J. Dettrey (2010) note that the effect of contact may be mitigated by strong predispositions. Their research on the relationship between knowing someone who is LGBQ and attitudes towards gay rights concluded that the contact effect varies based on the individual's political, religious, and cultural predispositions. They found that contact with LGBQ people had a positive effect on all groups, but a limited effect among the most conservatively minded-groups (e.g., evangelical conservatives; Skipworth, Garner, and Dettrey 2010). B. Bramlett's (2012) work demonstrated that even though contact with LGBQ people is associated with greater support for same-sex marriage, the extent may be limited or actually increase opposition for certain groups such as with White evangelical Protestants. Bramlett explains that evangelical Protestants endure in politics due to a separation from more secular society; the messages in their religious teachings may carry more weight than knowing someone who is LGBQ (Bramlett 2012). A. Garner's (2013) research revealed that interpersonal contact with LGBQ people induces ambivalence or cross-pressure among citizens with conservative-leaning predispositions (e.g., Republicans, evangelical Christians). Evangelical Christians who had no contact with LGBQ people had a more uniform position against gay marriage. Evangelicals with contact continued to be opposed to gay marriage generally, but their responses were less uniform and more dispersed across the range of options (Garner 2013).

Another factor to consider regarding the relationship between contact and attitudes towards LGBQ relationships and families is the direction of causation. Some note that the favorable attitudes professed by those who have contact with LGBQ people may precede the contact. They theorize that LGBQ people are more likely to reveal their sexual identity to those who hold positive, accepting attitudes towards same-sex relations (Lewis 2007; Skipworth, Garner, and Dettrey 2010). Herek and Capitanio's (1996) longitudinal research provided support for this supposition, finding that individuals with favorable attitudes toward gay men and lesbian women in Wave 1 were more likely than others to experience contact in Wave 2. Similarly, Lewis' (2007) research concluded that there is evidence of both causal directions, since people whose characteristics make them more likely to be accepting of same-sex attracted individuals are more likely to know LGB people. However, Lewis also notes that knowing an LGB person has a noticeable impact even when controlling for other factors, including previous beliefs about same-sex attracted individuals (Lewis 2007).

According to the most recent national survey on same-sex relationships in the U.S., two-thirds of Americans report having a close friend or family member who is gay or lesbian (65\%). Approximately seven in ten Millennials (71\%) and almost six in ten White evangelical Protestants (58\%) know someone who is 
LGBQ. Similar to previous trends, Millennials are the age cohort most likely to know someone who is LGBQ, whereas White evangelical Protestants are the religious tradition least likely (Jones, Cox, and Navarro-Rivera 2014).

\section{Millennials, Evangelical Protestants, and the Contact Hypothesis}

Millennials are less religious than older Americans. Almost one-fifth note that they were raised in a religion but are now unaffiliated with a particular faith. Millennials who do associate with a particular religious tradition, however, have similar levels of religious intensity to previous generations when they were young. For instance, 37 percent of Millennials consider themselves to be "strong" members of their faith. A comparable portion of Generation Xers and Baby Boomers asserted the same when they were younger (37\% and $31 \%$ respectively; Pond, Smith, and Clement 2010).

Currently, 22 percent of Millennials identify evangelical Protestant churches as their religious affiliation (Pond, Smith, and Clement 2010). There is some evidence that young people are leaving the evangelical tradition, considering themselves religious but unaffiliated or not religious. C. E. Smidt's (2013) work on American evangelicals notes that between 1964 and 2007, the evangelical Protestant tradition experienced a six percent decrease in those under the age of 35, the largest decrease among all of the affiliations examined (Smidt 2013, 81-82). Despite these changes, Smidt explains that a number of factors indicate that about one-quarter will continue to be evangelical in the future (e.g., evangelicals have larger families) (Smidt 2013, 225). Relatedly, a news release on the Public Religion Research Institute's 2013 LGBT Issues and Trends Survey titled, "American Religious Landscape Transforming as Support for Same-Sex Marriage Dramatically Increases," asserted that Millennials were leaving their childhood religions, specifying unfavorable church teachings about LGBT as the reason. It was also reported that a majority of Americans (51\%) perceive evangelical Christians to be one of the three religious groups unfriendly to LGBT people (Public Religion Research Institute 2014). No specific information was provided about whether Millennials were leaving evangelical Protestant churches in particular.

As a sub-population of both age and religion, there is limited research providing specifics on this group's attitudes about sexuality; however, the existing data reflects the contrasts of their age cohort and religious affiliation. The 2007 Pew Forum Religious Landscape survey found that 41 percent of Millennial evangelical Protestants agreed that "homosexuality should be accepted by society". This is 15 percentage points larger than non-Millennials (26\%) and 13 points larger than evangelical Protestants in general (28\% in agreement; Smidt 2013, 206). Compared with older members of their faith, larger percentages of Millennials believe that society should accept homosexuality (Pond, Smith, and Clement 2010).

The 2014 Public Religion Research Institute survey on LGBT issues and trends included a brief narrative analysis of age and religion. The results exemplify the tension between age and religious factors, and LGBT attitudes. The authors note that although only 27 percent of White evangelical Protestants 
support same-sex marriage, Millennial White evangelical Protestants are twice as likely to favor it (43\%) than older generations (Generation Xers 33\%, Baby Boomers 22\%, Silent Generation 19\%; Jones, Cox, and Navarro-Rivera 2014). A majority of Millennial White evangelical Protestants (66\%) believe gay and lesbian couples can be as good as parents as heterosexual couples, compared with a minority of the older generations who agree (32\%). Relatedly, Millennial White evangelical Protestants are twice as likely as the Silent Generation to support allowing gay and lesbian couples to adopt (46\% and $24 \%$ respectively; Jones, Cox, and Navarro-Rivera 2014).

To learn about how religious and political factors influence support for same-sex marriage, D.E. Sherkat, M. Powell-Williams, G. Maddox, and K. Mattias de Vries (2011) analyzed data from the General Social Survey. They find that religion plays a strong role, particularly within evangelical denominations. They explain that denominational ties and religious participation have a negative influence on support for LGBQ marriage rights. They comment that although some scholars have asserted that younger generations of conservative Christians are growing tolerant on sexuality issues, there continues to be a notable gap between the attitudes of younger conservative Christians and people with other or no faith commitments (Sherkat, Powell-Williams, Maddox, and Mattias de Vries 2011).

A consistent theme within the research literature is that evangelical Protestants are the religious tradition most opposed to same-sex relations, marriage, adoption, and parenting. Learning about the sexuality attitudes of the new generation of evangelical Protestant adults and how they are affected by contact with LGBQ people will provide insight into the Millennial evangelical Protestants' support or opposition to same-sex-headed families. Conversely, the work illustrated that Millennials are the age cohort most likely to favor legal support for same-sex families. Learning about the sexuality attitudes of the youngest generation of evangelical Protestants and how their attitudes are affected by contact will also illuminate the future relationship of Millennials with the evangelical Protestant tradition.

\section{Research Plan and Sampling}

\section{Methodology}

This project was part of a larger effort to learn about attitudes towards non-traditional families. The study used nonprobability sampling due to access to a sizeable group of participants attending a four-year, private, evangelical Christian college. Eighty-seven undergraduate students were recruited as volunteers from multiple sections of an introductory sociology course. Students enrolled in this general education course are more likely to be a cross-section of the student body than is it to be a concentration of sociology majors. Although a nonprobability sample of college students does not lead to results generalizable to the larger U.S. population, the conclusions will provide some understanding of the attitudes held by this specific demographic. The age range of the participants (93.0\% age $18-22,4 \%$ age $23-27 ; 2.3 \%$ did not respond) places them firmly in the Millennial generation. The survey instrument did not include questions 
regarding religious affiliation ${ }^{3}$, rather recent demographic information collected in the college's enrollment materials was used to understand the religious affiliation of the students. The vast majority of the college's students indicated that they have an evangelical Protestant affiliation (74.4\% evangelical Protestant, $23.8 \%$ mainline Protestant, $2.7 \%$ Roman Catholic, $0.2 \%$ other religions, $3.8 \%$ none/not stated). It was determined that these proportions would be the approximate composition of religious affiliation of students in general education courses such as the introduction to sociology class. Thus, the analysis was completed with the understanding that the findings would provide insight into the sexuality attitudes of Millennial Protestants (particularly evangelicals) with some college education.

Approximately 74 percent of the participants identified their race as White, 22 percent as non-White, and four percent did not respond. These percentages are extremely similar to the student body, which was 76 percent White, 22 percent non-White, and two percent without a response. It is also similar in racial composition to other private, four-year institutions (Aud, Fox, \& Kewal Ramani 2010). Approximately 76 percent of the participants were female, 22 percent male, and two percent did not respond. This is about a 25 percent difference from the student body ratio which is 54 percent female and 46 percent male. It differs by about 18 percent from other private schools (Borzelleca 2012).

The survey questions were developed using items from the Baylor Religion Survey (The Association of Religion Data Archives 2005), the Pew Research Religion and Public Life Project (Pew Research Center 2014c), and the Values and Beliefs section of the GALLUP Poll (GALLUP). The word 'homosexual' was replaced with 'same-sex' to reflect the most recent appropriate term (Lesbian Gay Bisexual Transgender Campus Resource Center). This internet survey was administered through Qualtrics. Participants scheduled appointments with the research team and went through an informed consent process upon arrival. Once the consent was given, participants were directed to a computer in a single-person lab room where they could complete the survey, which took approximately 15 minutes to accomplish. A small number of the participants (approximately 2-3) did not complete all of the questions in the survey. Thus some of the tables reflect a sample size smaller than 87 in regards to certain questions.

\section{Dependent Variables}

The first two dependent variables were responses to an introductory question:

${ }^{3}$ The overarching project on attitudes towards non-traditional families was initially focused on learning about interracial marriage and transracial adoption. Due to the emphasis on race, the inclusion of a religious affiliation variable was not considered. An exploratory analysis of all of the data identified these patterns regarding differing attitudes towards same-sex-headed families; however, it was recognized that since the student body is comprised primarily of evangelical Protestants, the results reflect the perspectives of the high level of religious affiliation of the population from which the sample was taken. 
How do you feel about the following marriage and family-related topics?

1. Same-sex marriages [General Attitude toward Marriage]

2. The adoption of a child by a gay couple [General Attitude toward SameSex Adoption]

These items were measured on a four-point scale: 1 - Always Wrong, 2 - Almost Always Wrong, 3 - Only Wrong Sometimes, and 4 - Not Wrong at All. The other dependent variables were responses to:

Indicate your level of agreement with each of the statements below.

3. Same-sex relations between consenting adults should be legal. [Same-Sex Relations Legal]

4. Marriages between people of the same-sex should be recognized by the law with the same rights as traditional marriages. [Same-Sex Marriage Legal]

5. Same-sex couples in long-term relationships should be able to adopt children. [Same-Sex Adoption Legal]

These items were measured on a five-point scale: 1 - Strongly Disagree, 2 Disagree, 3 - Neither Agree nor Disagree, 4 - Agree, and 5 - Strongly Agree.

\section{Independent Variables}

The questions for the independent variables measuring contact were located at the end of the survey with the demographic information.

1. Do you have any family members or close friends who identify as gay, lesbian, bisexual, or queer? [LGBQ Family/Friend]

2. Do you have any family members or close friends who are in a same-sex relationship? [LGBQ in Relationship]

These items were measured as $0-$ No and 1 - Yes.

\section{Analysis}

Descriptive statistics were run to learn about the demographics and contact with LGBQ persons. Cross-tabulations were completed to provide insight into the frequency and proportion of the two independent variables in regards to the five dependent variables.

Because the dependent variables have a logical sequential order, ordered logit was initially selected as most appropriate for this analysis. The test of parallel lines, however, was significant for two variables (General Attitude toward Marriage $\mathrm{p}=.023$, Same Sex Marriage Legal $\mathrm{p}=.012$ ) calling into question the assumption of proportional odds. Thus, the dependent variables were treated as categorical, and multinomial logistic regressions were completed with the independent variables of LGBQ Family/Friend and LGBQ in Relationship as the main predictors. Race and sex were included as control variables. 
The results revealed a pattern suggesting that contact with LGBQ people in a relationship had greater impact on attitudes than knowing someone who identifies at LGBQ. Since an exploratory analysis on the data revealed a nonnormal distribution, the nonparametric Mann-Whitney test was used to learn about the differences between these two groups (LGBQ Family/Friends Only - 1, LGBQ in Relationship - 2).

\section{Limitations}

The nonprobability sampling method and small number of participants prevents the results from being scientifically generalizable to any larger population. As with most research in which college students are used as a convenience sample, the conclusions are used to learn about this particular group and provide insight for future research (Babbie 2005, 188-189).

Regarding religion, the participants were not asked any questions about religious affiliation, church attendance, or other measures of religiosity. However, since three quarters of the college student body recently identified as evangelical Protestant in their admissions applications, it can be assumed that the majority of research participants are or recently have been affiliated with the tradition. Thus, the conclusions made are referred to as being about evangelical Protestants although no measures of religious affiliation or participation were recorded.

Regarding sex, a disproportionately high number of participants identified as female (76\%). It has been found that females may be slightly more supportive of LGBQ people and relationships than males (Jones, Cox, and Navarro-Rivera 2014; Olson, Cadge, and Harrison 2006). With this in mind, the sex variable is controlled in the multinomial regression analyses. Regarding race, the majority of the participants identified as White (74\%). White Americans are more likely to support same-sex marriage than groups of color (Jones, Cox, and Navarro-Rivera 2014; Sherkat, Powell-Williams, Maddox, \& Mattias de Vries 2011). Thus race is also controlled.

Regarding causal direction, it is recognized that, much like research on the relationship between LGBQ contact and attitudes towards same-sex relationships and families, this study cannot definitively establish that knowing someone who is LGBQ accounts for all of the change in an individual's opinions and attitudes (Lewis 2007). Since researchers have found that LGBQ contact does have impact when controlling for previously established beliefs, the authors acknowledge that this is a limitation of the project.

\section{Frequency of Contact}

\section{Findings}

Almost half of the participants $(48.2 \%)$ indicate having a close friend or family member who is LGBQ. One-quarter (24.7\%) know someone in a samesex relationship (Table 1). These percentages are lower than both Millennials (71\%) and evangelical Protestants (58\%) in the general public (Jones, Cox, and Navarro-Rivera 2014), yet demonstrate that contact is occurring. 
Table 1: Participants' Contact with LGBQ People

Have LGBQ Family/Friends

Know LGBQ in Relationship

\begin{tabular}{llllll}
\hline & Frequency & Percent & & Frequency & Percent \\
\hline No & 44 & 51.8 & & 64 & 75.3 \\
Yes & 41 & 48.2 & & 21 & 24.7 \\
\hline Total & 85 & 100.0 & & 85 & 100.0
\end{tabular}

\section{Attitudes Regarding Whether Same-Sex Marriage is Wrong}

Regarding general attitudes about same-sex marriage, attitudes of those with LGBQ family and friends are similar to those without with the exception that those without LGBQ family and friends are much more likely to consider it always wrong. This pattern is evident in the relevant percentages in Table 2 showing that 42.5 percent of those with LGBQ family and friends believe it is always wrong compared to 75 percent of those who do not have LGBQ family or friends.

Table 2: Cross-tabulation of Types of Contact with LGBQ People and Attitudes towards Same-Sex-Headed Families in General

\begin{tabular}{|c|c|c|c|c|c|c|c|c|c|c|c|c|}
\hline \multirow[b]{2}{*}{$\begin{array}{l}\text { How do you feel about } \\
\text { the following marriage } \\
\text { and family-related } \\
\text { topics? }\end{array}$} & \multicolumn{4}{|c|}{$\begin{array}{l}\text { Almost } \\
\text { Always } \\
\text { Wrong } \\
(2)\end{array}$} & \multicolumn{2}{|c|}{$\begin{array}{l}\text { Only Wrong } \\
\text { Sometimes } \\
\text { (3) }\end{array}$} & \multicolumn{2}{|c|}{$\begin{array}{l}\text { Not Wrong } \\
\text { At All (4) }\end{array}$} & \multicolumn{2}{|c|}{ Total } & \multicolumn{2}{|c|}{ Means } \\
\hline & $\begin{array}{l}\% \\
\text { No }\end{array}$ & $\begin{array}{l}\% \\
Y e s\end{array}$ & $\begin{array}{c}\% \\
\text { No }\end{array}$ & $\begin{array}{l}\% \\
Y e s\end{array}$ & $\begin{array}{c}\% \\
\text { No }\end{array}$ & $\begin{array}{l}\% \\
Y e s\end{array}$ & $\begin{array}{l}\% \\
\text { No }\end{array}$ & $\begin{array}{l}\% \\
Y e s\end{array}$ & $\begin{array}{l}\% \\
\text { No }\end{array}$ & $\begin{array}{l}\% \\
\text { Yes }\end{array}$ & $\begin{array}{c}\% \\
\text { No }\end{array}$ & $\begin{array}{l}\% \\
Y e s\end{array}$ \\
\hline $\begin{array}{l}\text { Same-sex marriages? } \\
\text { Have LGBQ Family \& } \\
\text { Friends }\end{array}$ & 75.0 & 42.5 & 4.5 & 15.0 & 2.3 & 10.0 & 18.2 & 32.5 & 100 & 100 & 1.64 & 2.33 \\
\hline $\begin{array}{l}\text { Know LGBQ in } \\
\text { Relationship }\end{array}$ & 71.4 & 23.8 & 6.3 & 19.0 & 4.8 & 9.5 & 17.5 & 47.6 & 100 & 100 & 1.68 & 2.81 \\
\hline $\begin{array}{l}\text { Adoption of a Child by a } \\
\text { Gay Couple? } \\
\text { Have LGBQ Family \& } \\
\text { Friends }\end{array}$ & 31.8 & 17.5 & 27.3 & 12.5 & 13.6 & 32.5 & 27.3 & 37.5 & 100 & 100 & 2.36 & 2.90 \\
\hline $\begin{array}{l}\text { Know LGBQ in } \\
\text { Relationship }\end{array}$ & 28.6 & 14.3 & 25.4 & 4.8 & 17.5 & 38.1 & 28.6 & 42.9 & 100 & 100 & 2.46 & 3.10 \\
\hline
\end{tabular}

Participants who know someone in a same-sex relationship have varied responses to general attitudes about same-sex marriage. A notable amount consider it always wrong (23.8\%) or almost always wrong (19.0\%), but almost half of these participants (47.6\%) state that it is not wrong at all (Table 2). This finding is in stark contrast to those who do not know someone in a same-sex relationship, among whom 71.4 percent consider same-sex marriage always wrong and only 17.5 percent believe it is not wrong at all (Table 2). The results of the multinomial logit reveal that those who do not know someone in a same- 
sex relationship are over seven times more likely to consider same-sex marriage to be always wrong rather than not wrong at all in comparison to those who do know someone in a LGBQ relationship (odds ratio $=7.23, \mathrm{p}=.023$, Table 3 ).

\section{Table 3: Odds Ratios (OR) for a Multinomial Logistic Regression of General Attitudes towards Same-sex} Marriages on Contact with LGBQ with Various Control Variables

How do you feel about the following marriage and family-related

\begin{tabular}{|c|c|c|c|c|}
\hline topics? - Same-sex marri & & OR & SE & $p$ \\
\hline \multirow[t]{5}{*}{ Always Wrong } & Intercept & & .601 & .293 \\
\hline & Have LGBQ Fam/Friend? No & 1.114 & .817 & .895 \\
\hline & Know LGBQ in Relationship? No & 7.231 & .867 & .023 \\
\hline & Race $=$ Non White & 1.053 & .729 & .943 \\
\hline & Sex $=$ Male & .751 & .648 & .659 \\
\hline \multirow[t]{5}{*}{ Almost Always Wrong } & Intercept & & .711 & .220 \\
\hline & Have LGBQ Fam/Friend? No & .473 & 1.301 & .566 \\
\hline & Know LGBQ in Relationship? No & 1.487 & 1.120 & .723 \\
\hline & Race $=$ Non White & 1.629 & .968 & .614 \\
\hline & Sex $=$ Male & .352 & 1.179 & .375 \\
\hline \multirow[t]{5}{*}{ Only Wrong Sometimes } & Intercept & & .857 & .118 \\
\hline & Have LGBQ Fam/Friend? No & .145 & 1.464 & .187 \\
\hline & Know LGBQ in Relationship? No & 3.832 & 1.230 & .275 \\
\hline & Race $=$ Non White & .482 & 1.304 & .576 \\
\hline & Sex $=$ Male & .628 & 1.234 & .707 \\
\hline
\end{tabular}

- Reference category is "Not Wrong At All"

- Statistically significant predictors in bold

\section{Attitudes Regarding Whether Same-Sex Adoption is Wrong}

Regarding general attitudes towards same-sex-headed families, participants were a bit more supportive of same-sex adoption than they were of same-sex marriage. Opinions about same-sex adoption were also more varied than those expressed about same-sex marriage. Almost one-third of participants with LGBQ family members or friends considered the adoption of a child by a gay couple wrong $(17.5 \%$ always wrong $+12.5 \%$ almost always wrong), another third considered it only wrong sometimes $(32.5 \%)$, and the final third considered it not wrong at all (37.5\%, Table 2). Comparatively, a slightly larger proportion of people without LGBQ family members or friends considered it always wrong (31.8\%) or almost always wrong (27.3\%) compared to those who think it is only wrong sometimes or not wrong at all (13.6\% and $27.3 \%$ respectively, Table 2$)$.

A similar pattern was identified regarding LGBQ contact with many of the participants who know someone in a same-sex relationship indicating that the adoption of a child by a gay couple is not wrong at all (42.9\%) which differs from 
the majority of participants who do not know someone in a same-sex relationship considering adoption of a child by a gay couple wrong (almost always wrong $25.4 \%+$ always wrong $28.6 \%$, Table 2 ). The mean of 3.10 for those who know someone in a same-sex relationship compares to the mean of 2.46 for those who do not, showing that each group tends to fall on opposite sides of the issue (Table 2 ). This difference is not statistically significant in the multinomial logit results (Table 4).

\section{Table 4: Odds Ratios (OR) for a Multinomial Logistic Regression of General Attitudes towards Same-sex} Adoption on Contact with LGBQ with Various Control Variables

How do you feel about the following marriage and family-related topics? - The adoption of a child by a gay couple

\begin{tabular}{llrrr} 
topics? - The adoption of a child by a gay couple & OR & \multicolumn{2}{c}{$p$} & .109 \\
Always Wrong & Intercept & & .736 & .449 \\
& Have LGBQ Fam/Friend? No & 1.900 & .847 & .511 \\
& Know LGBQ in Rel? No & 1.858 & .944 & .670 \\
& Race = Non White & 1.395 & .781 & .826 \\
\hline & Sex = Male & .848 & .751 & .036 \\
Almost Always Wrong & Intercept & & 1.103 & .470 \\
& Have LGBQ Fam/Friend? No & 1.912 & .897 & .231 \\
& Know LGBQ in Rel? No & 4.682 & 1.289 & .900 \\
& Race = Non White & .893 & .903 & .484 \\
\hline & Sex = Male & 1.693 & .753 & .949 \\
\hline Only Wrong Sometimes & Intercept & & .553 & .396 \\
& Have LGBQ Fam/Friend? No & .490 & .841 & .965 \\
& Know LGBQ in Rel? No & 1.035 & .795 & .498 \\
& Race = Non White & .595 & .766 & .922 \\
\hline & Sex = Male & .931 & .738 & .155 \\
& Nagelkerke Pseudo R2 & &
\end{tabular}

- Reference category is "Not Wrong At All"

\section{Should Same-Sex Relationships be Legal?}

The first of these findings regarding the legality of same-sex-headed families, reveals that contact seems to influence or predict attitudes. Participants with LGBQ family members or friends indicate a variety of opinions about whether romantic relationships between same-sex people should be legal, yet a large portion of this group choose to neither agree nor disagree with the statement "Same-sex relations between consenting adults should be legal," (37.5\%, Table 5). This contrasts with participants who do not have LGBQ family members or friends among whom the majority strongly disagreed (52.3\%, Table $5)$. 
Table 5: Cross-tabulation of Types of Contact with LGBQ People and Attitudes towards Legalization of Same-Sex-Headed Families

\begin{tabular}{cccccccccccccc}
$\begin{array}{c}\text { Strongly } \\
\text { Disagree (1) }\end{array}$ & Disagree (2) & Neither (3) & Agree (4) & Strongly \\
Agree (5) & Total & Means \\
\hline$\%$ & $\%$ & $\%$ & $\%$ & $\%$ & $\%$ & $\%$ & $\%$ & $\%$ & $\%$ & $\%$ & $\%$ & $\%$ & $\%$ \\
No & Yes & No & Yes & No & Yes & No & Yes & No & Yes & No & Yes & No & Yes \\
\end{tabular}

Same-sex relations between consenting adults should be legal

Have LGBQ

Family \& Friends

Know LGBQ in

Relationship

$42.9 \quad 4.8 \quad 19.0$

12.5

$15.9 \quad 37.5$

13.6

20.0

$2.3 \quad 17.5 \quad 100$

100

1.98

3.18

Marriage between people of the same-sex should be recognized by law

Have LGBQ
Family \& Friends
Know LGBQ in
Relationship

$\begin{array}{llll}52.3 & 17.5 & 20.5 & 12.5\end{array}$

2.3

$\begin{array}{lll}44.4 & 9.5 & 19.0\end{array}$

9.5

7.9

22.5

22.7

30.0

$2.3 \quad 17.5$

100

100

2.02

3.18

Same-sex couples in long-term relationships should be able to adopt children

Have LGBQ

Family \& Friends

Know LGBQ in

Relationship

$\begin{array}{lrrrrrrr}22.7 & 10.0 & 20.5 & 15.0 & 25.0 & 30.0 & 29.5 & 27.5 \\ 20.6 & 4.8 & 20.6 & 9.5 & 25.4 & 33.3 & 30.2 & 23.8\end{array}$

3.

$2.3 \quad 17.5$

$17.5-100$

$3.2 \quad 28.6 \quad 100$

100

2.75

3.28

3.62

A similar, yet more distinct theme surfaces among those who know someone in a same-sex relationship regarding legalizing same-sex relations. Of the participants who know someone in a same-sex relationship, the greatest portion chose to neither agree nor disagree with the statement "Same-sex relations between consenting adults should be legal," (47.6\%, Table 5). Additionally, the other participants indicating knowing someone in a same-sex relationship were more likely to agree (19.0\%) or strongly agree (28.6\%) than to strongly disagree with the statement (4.8\%, Table 5). This pattern differs from those who do not know someone in a same-sex relationship among whom the greatest portion disagreed (42.9\% strongly disagree, 19\% disagree), and less than one-fifth agreed (3.2\% strongly agree, $15.9 \%$ agree; Table 5).

It is important to note that no participants who know someone in a samesex relationship disagreed with the statement, "Same-sex relations between consenting adults should be legal," ( $0 \%$ disagree, Table 5). For this reason the five-point Likert scale ranging from strongly disagree to strongly agree was collapsed into a three-point scale combining all participants who disagreed (strongly disagree and disagree) into one point and combining all participants who agreed (strongly agree and agree) into another point while leaving those who neither agree nor disagree remaining as the middle point. This made it possible to analyze using multinomial logit. Table 6 details the results which reveal that people who do not know someone in a same sex relationship are almost 20 times more likely to disagree than to agree that same-sex relationships between consenting adults should be legal $(\mathrm{OR}=19.48, \mathrm{p}<.05)$. The statistically 
significant coefficient for the control variable of sex $(\mathrm{OR}=.176, \mathrm{p}<.05)$ may suggest that male participants in this sample were slightly less likely to neither agree nor disagree rather than to agree in comparison to female participants (Table 6). This is an interesting finding that could be explored in future studies that have a more representative gender sample.

Table 6: Odds Ratios (OR) for a Multinomial Logistic Regression of Attitudes towards Legalizing Same-sex Relationships on Contact with LGBQ with Various Control Variables

Indicate your level of agreement with each of the statements below.Same-sex relations between consenting adults should be legal. Disagree

\begin{tabular}{|c|c|c|c|c|}
\hline & \multirow[b]{2}{*}{ Have LGBQ Fam/Friend? No } & & \multirow[b]{2}{*}{0.784} & \multirow[b]{2}{*}{.422} \\
\hline & & 1.878 & & \\
\hline & Know LGBQ in Rel? No & 19.480 & 1.226 & .015 \\
\hline & Race $=$ Non White & 0.446 & 0.763 & .290 \\
\hline & Sex = Male & 0.629 & 0.691 & .502 \\
\hline \multirow[t]{6}{*}{ Neither } & Intercept & & .550 & .282 \\
\hline & Have LGBQ Fam/Friend? No & 0.744 & 0.920 & .744 \\
\hline & Know LGBQ in Rel? No & 0.870 & 0.833 & .870 \\
\hline & Race $=$ Non White & .326 & .753 & .326 \\
\hline & Sex = Male & .176 & 0.871 & .046 \\
\hline & Nagelkerke Pseudo R2 & .373 & & \\
\hline
\end{tabular}

- Reference category is "Agree"

- Statistically significant predictors in bold

Note: Due to small cells the five-point Likert Scale was collapsed into three-points making it possible to analyze using multinomial logit.

\section{Should Same-Sex Marriage be Legal?}

A slightly greater portion of participants who know someone who is LGBQ agree that same-sex marriage should be legal (strongly agree $17.5 \%$, agree $30.0 \%$ ), whereas the majority of participants who do not know someone who is LGBQ disagree that same-sex marriage should be legal (52.3\% strongly disagree, $20.5 \%$ disagree, Table 5). There is a 1.16 point difference in means between these two groups with participants having LGBQ family members and friends at an average of 3.18 (slightly higher than neither agree nor disagree) and participants without LGBQ family members or friends at 2.02 (disagree, Table 5).

Similar to knowing someone who is LGBQ, participants who know someone in a same-sex relationship were much more likely to agree that same-sex marriage should be legal (23.8\% strongly agree, $33.3 \%$ agree) whereas those who do not know someone in a same-sex relationship were more likely to disagree (44.4\% strongly disagree, $19.0 \%$ disagree; Table 5). A 1.27 point difference in means (3.52 for those know someone in a same-sex relationship, 2.25 for those who do not) show that participants in these groups indicate differing opinions on same-sex marriage with each group landing on opposite side 
of neither agree nor disagree (Table 5). These differences in attitudes towards same-sex marriage between those who do not have contact with LGBQ people and those who do were not found to be statistically significant according to the results of the multinomial logit (Table 7).

Table 7: Odds Ratios (OR) for a Multinomial Logistic Regression of Attitudes towards Legalizing Same-sex

Marriage on Contact with LGBQ with Various Control Variables

Indicate your level of agreement with each of the statements below.-

Marriages between people of the same-sex should be recognized by the law with the same rights as traditional marriages.

\begin{tabular}{|c|c|c|c|c|}
\hline \multicolumn{2}{|c|}{ With the same rignts as traditional marriages. } & UR & \multicolumn{2}{|l|}{ SE } \\
\hline \multirow{5}{*}{$\begin{array}{l}\text { With the same righ } \\
\text { Strongly Disagree }\end{array}$} & Intercept & & .918 & .429 \\
\hline & Have LGBQ Fam/Friend? No & 6.730 & 1.388 & .169 \\
\hline & Know LGBQ in Rel? No & 7.591 & 1.223 & .097 \\
\hline & Race $=$ Non White & .447 & 1.044 & .440 \\
\hline & Sex $=$ Male & 1.053 & 1.027 & .960 \\
\hline \multirow[t]{5}{*}{ Disagree } & Intercept & & .953 & .371 \\
\hline & Have LGBQ Fam/Friend? No & 8.691 & 1.556 & .165 \\
\hline & Know LGBQ in Rel? No & 2.400 & 1.336 & .512 \\
\hline & Race $=$ Non White & 1.161 & 1.129 & .895 \\
\hline & Sex $=$ Male & .558 & 1.202 & .628 \\
\hline \multirow[t]{5}{*}{ Neither } & Intercept & & .758 & .780 \\
\hline & Have LGBQ Fam/Friend? No & .486 & 1.731 & .677 \\
\hline & Know LGBQ in Rel? No & 2.029 & 1.109 & .523 \\
\hline & Race $=$ Non White & .916 & 1.034 & .932 \\
\hline & Sex $=$ Male & .336 & 1.338 & .415 \\
\hline \multirow[t]{5}{*}{ Agree } & Intercept & & .704 & .600 \\
\hline & Have LGBQ Fam/Friend? No & 3.239 & 1.403 & .402 \\
\hline & Know LGBQ in Rel? No & 2.051 & 1.058 & .497 \\
\hline & Race $=$ Non White & .593 & .960 & .586 \\
\hline & Sex $=$ Male & 1.464 & .966 & 693 \\
\hline
\end{tabular}

Nagelkerke Pseudo R2

- Reference category is "Strongly Agree"

\section{Should Same-Sex Adoption be Legal?}

Similar to general attitudes towards same-sex adoption, opinions about the legalization of same-sex adoption were varied. Participants who know someone who is LGBQ and those who know someone in a same-sex relationship were slightly more likely than their counterparts to agree that it should be legal, but no significant trends were identified (Table 5). Table 5 shows that the difference in the means ranged from 1.16 to 1.50 between those with and without LGBQ contact regarding the legalization of same-sex relations and same-sex marriage respectively. Yet the difference in means regarding the legalization of same-sex 
adoption was only .60 between those who do and do not know someone who is LGBQ and .87 between those who know someone in a same-sex relationship and those who do not (Table 5) illustrating the low level of contact-associated variability within this dependent variable. The lack of statistically significant predictors in the multinomial logit underscores these trends (Table 8).

Table 8: Odds Ratios (OR) for a Multinomial Logistic Regression of Attitudes towards Legalizing Same-sex Adoption on Contact with LGBQ with Various Control Variables

Indicate your level of agreement with each of the statements below. -

Same-sex couples in long-term relationships should be able to adopt

\begin{tabular}{|c|c|c|c|c|}
\hline children. & & OR & SE & $p$ \\
\hline \multirow[t]{5}{*}{ Strongly Disagree } & Intercept & & 1.162 & .098 \\
\hline & Have LGBQ Fam/Friend? No & 3.544 & 1.633 & .438 \\
\hline & Know LGBQ in Rel? No & 17.549 & 1.611 & .075 \\
\hline & Race $=$ Non White & 1.163 & 1.214 & .901 \\
\hline & Sex $=$ Male & 1.367 & 1.130 & .782 \\
\hline \multirow[t]{5}{*}{ Disagree } & Intercept & & .936 & .201 \\
\hline & Have LGBQ Fam/Friend? No & 2.111 & 1.625 & .646 \\
\hline & Know LGBQ in Rel? No & 12.332 & 1.470 & .087 \\
\hline & Race $=$ Non White & .235 & 1.439 & .315 \\
\hline & Sex $=$ Male & 2.284 & 1.090 & .449 \\
\hline \multirow[t]{5}{*}{ Neither } & Intercept & & .673 & .941 \\
\hline & Have LGBQ Fam/Friend? No & 2.653 & 1.577 & .536 \\
\hline & Know LGBQ in Rel? No & 3.636 & 1.255 & .303 \\
\hline & Race $=$ Non White & 1.871 & 1.011 & .536 \\
\hline & Sex $=$ Male & .674 & 1.040 & .704 \\
\hline \multirow[t]{5}{*}{ Agree } & Intercept & & .707 & .809 \\
\hline & Have LGBQ Fam/Friend? No & 2.467 & 1.557 & .562 \\
\hline & Know LGBQ in Rel? No & 6.602 & 1.263 & .135 \\
\hline & Race $=$ Non White & 1.361 & 1.044 & .768 \\
\hline & Sex $=$ Male & .647 & 1.056 & 680 \\
\hline
\end{tabular}

-Reference category is "Strongly Agree"

\section{Impact of Types of Contact}

A review of the cross-tabulations seems to show that participants who know LGBQ people in relationships are more likely to support same-sex-headed families legally and in general compared to people who have LGBQ family members or friends (Tables 2 and 5). Regarding general attitudes towards samesex marriage, the odds ratio for those who do not know someone in a same-sex relationship (7.23) is much greater (and statistically significant) compared to the odds ratio of those who do not have LGBQ identifying family or friends (1.11, not statistically significant) when comparing always wrong to not wrong at all (Table 
3). Additionally, less than five percent of people who know someone in a LGBQ relationship disagreed with the statement, "Same-sex relations between consenting adults should be legal," (4.8\% strongly disagree, $0.0 \%$ disagree), whereas a quarter of participants who have LGBQ family and friends disagreed with the statement (12.5\% strongly disagree, $12.5 \%$ disagree; Table 5).

For these reasons, the difference in the impact of types of contact was analyzed. Participants who had LGBQ contact were categorized into two groups: 1) those with LGBQ family and friends but who do not know someone in a samesex relationship and 2) those who know LGBQ people in a relationship. The categorical nature of the dependent variables, their non-normal distribution, and the dichotomous categorical independent variable lead to the application of the Mann-Whitney test (Table 9). Attitudes towards same-sex marriage in general significantly differed between those who have family and friends that are LGBQ $(M d n=1.00)$ and those who know LGBQ people in relationships $(M d n=3.00$, Table 9) with the latter having a greater impact. Attitudes towards legalizing same-sex relations also differed between the two groups (LGBQ family/friends $M d n=3.00$, LGBQ in relationship $M d n=4.00$; Table 9) demonstrating the greater prediction ability of contact with those in LGBQ relationships in this regard. There were no difference in medians for the three other dependent variables (Table 9).

\begin{tabular}{|c|c|c|c|c|}
\hline & $\begin{array}{r}\text { LGBQ Family/Friends } \\
\text { Median }\end{array}$ & $\begin{array}{l}\text { ationship } \\
\text { Median }\end{array}$ & $U$ & $\mathrm{r}$ \\
\hline General Attitude toward Marriage & 1.00 & 3.00 & $112.0 *$ & -0.40 \\
\hline General Attitude Same-sex Adoption & 3.00 & 3.00 & 159.0 & -0.18 \\
\hline Same-sex Relations Legal & 3.00 & 3.00 & $107.0 * *$ & -0.41 \\
\hline Same-sex Marriage Legal & 3.00 & 4.00 & 139.5 & -0.26 \\
\hline Same-sex Adoption Legal & 3.00 & 4.00 & 135.0 & -0.28 \\
\hline
\end{tabular}

$* \mathrm{p}<.05 ; * * \mathrm{p}<.01$

\section{Discussion}

The primary contributions of this project to the scholarship on Millennial evangelical Protestant's attitudes towards options for creating same-sex-headed families include the following findings: 1) contact with LGBQ people is occurring; 2) contact with LGBQ people is likely to increase support for samesex-headed families; 3) contact with LGBQ people in same-sex relationships may result in more support than only contact with close family members or friends who identify as LGBQ; 4) contact does not result in uniform support for same-sex families, but may be best described as creating ambivalence among this unique group; and 5) support for same-sex marriage differs in distinct ways than support for same-sex adoption.

Regarding frequency of contact, it may be logical to assume that students attending a private, evangelical Protestant college would not have LGBQ 
identifying people in their network of close family members and friends. The findings show that, although this group has fewer relationships with LGBQ people than those in the general population, these relationships do exist. Almost half of the participants indicated having a close family member or friend identify as LGBQ, and one quarter indicated having a close family member or friend in a same-sex relationship (Table 1). It is clear that these Millennial evangelical Protestants are not isolated from LGBQ people or same-sex relationships, in spite of their religious affiliation and college attendance at an evangelical Protestant institution.

Regarding the influence of contact, the multinomial logistic regressions revealed that knowing someone in a same-sex relationship predicts more favorable attitudes towards same-sex marriage in general (Table 3) and for legalizing same-sex relationships (Table 6) among these Millennial evangelical Protestants. Additionally, the Mann-Whitney test identified that knowing someone in a same-sex relationship is a better predictor of attitudes towards the same dependent variables than only having LGBQ family members and friends (Table 9). One may conclude that in regards to certain aspects of creating samesex-headed families (particularly same-sex marriage and legalizing same-sex relationships), knowing someone who identifies as lesbian, gay, bisexual, or queer may have some influence on attitudes, yet knowing someone in a same-sexheaded family (the same-sex romantic relationship) is much more influential on attitudes.

In addition to learning about the impact that contact with LGBQ people may have on attitudes about same-sex families, the attitudes espoused provided insight into their opinions about same-sex-headed families in general. Similar to trends identified in related research, these Millennial evangelical Protestants were not overwhelmingly supportive or opposed to legalization of options used to create same-sex-headed families. Approximately one-third agreed that same-sex marriage should be legal, whereas more than half disagreed (Table 5). Similarly, almost 40 percent indicated that same-sex adoption should be legal with one-third disagreeing, and the remaining quarter neither agreeing nor disagreeing (Table 5). Combined with the findings regarding the influence of contact with LGBQ people, particularly people in same-sex relationships, it can be theorized that although Millennials have relatively negative or neutral attitudes about the morality and legal status of same-sex families, they may develop more favorable attitudes if their network of family and friends includes LGBQ people, especially those in same-sex relationships. Millennials who expressed opposition could develop more ambivalent attitudes. Millennials who were previously ambivalent could become more supportive.

Considering the various facets of creating same-sex-headed families, it is notable that when reviewing the participants' opinions in aggregate, although a distinct portion of participants were opposed to same-sex marriage generally $(69.0 \%)$ and legally $(52.4 \%)$, there was less opposition to same-sex couples adopting (in general $45.2 \%$, legally $34.6 \%$ ). Relatedly, although contact with people who are LGBQ or same-sex couples had a significant impact on attitudes towards same-sex marriage in general and legalizing same-sex relations (Tables 3 
and 6), it did not affect attitudes towards same-sex adoption. A variation in impact with LGBQ individuals and same-sex couples on attitudes towards different types of same-sex-headed families was also evident in the work of Barth and Parry (2009), who determined that same-sex couples had more impact on attitudes towards same-sex marriage, whereas simply knowing someone who is lesbian or gay better predicted attitudes towards same-sex adoption.

Additionally, a trend evident but not discussed in the work of Jones, Cox and Rivera (2014) showed White evangelical Protestant support for same-sex marriage at 27 percent and their support for same-sex adoption at 33 percent. Also, almost half (49.0\%) of White evangelical Protestants agreed that gay and lesbian couples can be as good as parents as heterosexual couples. These findings hint at a pattern in which Millennial evangelical Protestants may be more supportive of same-sex couples as parents than they are of same-sex marriage. One theory could be that moral opposition to same-sex romantic relationships may not always extend to negative opinions about LGBQ people as parents. Differences in attitudes towards different types of same-sex-headed families and how they are impacted by various types of contact with LGBQ people should be explored in future research.

\section{Implications}

Knowing about these Millennial evangelical Protestants' attitudes towards same-sex relationships and the influence of contact on their attitudes has implications for individuals and organizations that seek moral and legal support for options to create same-sex-headed families. First, those in LGBQ supportive movements should be aware that a particular segment of Millennials may not be as overwhelming supportive as Millennials in the general population. Although Millennials in other religious traditions may disagree with their institutions' stance on same-sex relationships, evangelical Protestant Millennials seem to be more likely to have attitudes consistent with their institution's religious affiliation. Second, since contact with LGBQ people increases the likelihood that the person will have more favorable attitudes towards same-sex-headed family options, it is possible that efforts to develop interpersonal relationships with Millennial evangelical Protestants may be more effective than other methods of influence (e.g., political discourse, demonstrations).

Regarding the implications for evangelical Protestantism, it will be important for the tradition to recognize that, although Millennial evangelicals may espouse attitudes only slightly more favorable to same-sex-headed families than the tradition in general, they are part of the age cohort exhibiting the greatest amount of change in same-sex attitudes. Combined with the data that Millennials have contact with LGBQ people and their families, and that contact may influence their attitudes about same-sex families, evangelical leaders should expect more change toward support for LGBQ rights to occur. Recognizing that a number of Millennials are disaffiliating with specific Protestant traditions, and that almost all other traditions have more favorable attitudes towards same-sex relationships than evangelical Protestantism, the topic of sexuality should be handled with particular care. 
Future research on this topic should more thoroughly explore three of the identified trends. First, this survey involved two indicators of contact (knowing someone who is LGBQ and knowing someone in a same-sex relationship). Information on the number, types of relationships, and strength of relationships could be gathered for a more complete understanding of the influence of certain types of contact. If knowing someone who is in a same-sex relationship has more influence than simply knowing someone who identifies as LGBQ, it may be possible that knowing LGBQ couples who are married, are parents, or who have adopted will have even greater impact on attitudes towards same-sex-headed families. Second, the questions regarding same-sex relationships and marriage elicited more polarizing responses than the question regarding whether same-sex couples should be able to adopt. Future efforts should differentiate questions regarding morality, legalization, and perception of same-sex couples as parents. Third, these Millennial evangelical Protestants were more supportive of same-sexheaded families than the average member of their religious tradition, but less supportive than their generational cohort, despite contact with LGBQ people. Other influences such as religious teachings, religious institutional positions, legal rulings, and peer perspectives should be considered in future research to better understand how this new generation of adults form opinions about same-sexheaded family creation.

\section{References}

Amir, Yehuda. 1998. "Contact Hypothesis in Ethnic Relations." pp. 162-181 in The Handbook of Interethnic Coexistence, edited by E. Weiner. New York: Continuum Publishing.

Aud, S., Fox, M. A., \& Kewal Ramani, A. (2010). Status and Trends in the Education of Racial and Ethnic Groups (pp. 128). Washington D.C.: National Center for Education Statistics.

The Association of Religion Data Archives. 2005. "Baylor Religion Survey: Codebook." The Association of Religion Data Archives.

—. 2010. "Evangelical Protestant Denominations." The Association of Relgion Data Archives.

Babbie, Earl. 2005. The Basics of Social Research: Belmont, CA: Thomson Wadsworth.

Barth, Jay and Janine Parry. 2009. " $2>1+1$ ? The Impact of Contact with Gay and Lesbian Couples on Attitudes about Gays/Lesbians and Gay -Related Policies." Politics \& Policy 37:31-50. doi: 10.1111/j.17471346.2007.00160.x

Baunauch, Dawn Michelle. 2011. "Decomposing Trends in Attitudes Toward Gay Marriage, 1988-2006." Social Science Quarterly 92:346-363. doi: 10.1111/j.1540-6237.2011.00772.x

Borzelleca, D. (2012). The Male-Female Ratio in College Retrieved October 2014, from http://www.forbes.com/sites/ccap/2012/02/16/the-malefemale-ratio-in-college/ 
Bramlett, Brittany H. 2012. "The Cross-Pressures of Religion and Contact with Gays and Lesbians, and Their Impact on Same-Sex Marriage Opinion." Politcs and Policy 40:13-42. doi: 10.1111/j.1747-1346.2011.00337.x

Caspi, Avshalom. 1984. "Contact Hypothesis and Inter-Age Attitudes: A Field of Cross-Age Contact." Social Psychological Quarterly 47:74-80.

Chang Wei, Christina, Lutz Berkner, Shirley He, Stephen Lew, Mellissa Cominole, Peter Siegel, and James Griffith. 2009. "2007-08 National Postsecondary Student Aid Study: Student Financial Aid Estimates for 2007-08." U.S. Department of Education, National Center for Education Statistics.

Dimock, M., C Doherty, and J. Kiley. 2013. "Growing Support for Gay Marriage: Changed Minds and Changing Demographics." Gen 10:1965-1980.

Dovidio, John F., Peter Glick, and Laurie A. Rudman. 2005. "On the Nature of Prejudice: Fifty Years after Allport." Malden, MA: Blackwell Publishing.

GALLUP. 2014. "Gay and Lesbian Rights." GALLUP. Http:// http://www.gallup.com/poll/1651/Gay-Lesbian-Rights.aspx

Garner, Andrew. 2013. "Ambivalence, the Intergroup Contact Hypothesis, and Attitudes about Gay Rights." Politics and Policy 41:241-266. doi: 10.1111/polp.12010

Green, Donald P. and Janelle S. Wong. 2009. "Tolerance and the Contact Hypothesis: A Field Experiement." Pp. 228-246 in The Political Psychology of Democratic Citizenship, Series in Policial Psychology, edited by E. Borgida, C. M. Federico, and J. L. Sullivan. New York, NY: Oxford University Press.

Herek, Gregory M. and John P. Capitanio. 1996. ""Some of My Best Friends": Intergroup Contact, Conceleable Stigma, and Heterosexuals' Attitudes Towards Gay Men and Lesbians." Personality and Social Psychology Bulletin 22:412-424.

Jones, Robert P., Daniel Cox, and Juhem Navarro-Rivera. 2014. "A Shifting Landscape: A Decade of Change in American Attitudes about Same-Sex Marriage and LGBT Issues." Public Religion Research Institute, Washington, DC.

Lewis, Grebory B. 2007, September 2. "Personal Relationships and Support for Gay Rights." Paper presented at the Annual Meeting of the American Political Science Association, Philadelphia, PA.

Lewis, Gregory B. 2011. "The Friends and Family Plan: Contact with Gays and Support for Gay Rights." Policy Studies Journal 39:217-238. doi: 10.1111/j.1541-0072.2011.00405.x

Lesbian Gay Bisexual Transgender Campus Resource Center. "LGBTQI Terminology." edited by A. D. o. S. Affairs. Los Angeles, CA: UCLA. Markoe, Lauren. 2014. "CORRECTION: Presbyterians Vote to Allow Gay Marriage." in Religion News Service. Washington, D.C.: The Washington Post. Http://www.washingtonpost.com/national/religion/correctionpresbyterians-vote-to-allow-gay-marriage/2014/06/24/7727e8dc-fbd311e3-b8bf-54b8afb537b6_story.html 
Masci, David and Michael Lipka. 2015. "Where Christian Churches, Other Religions Stand on Gay Marriage." Washington, D.C.: Pew Research Center.

Olson, Laura R., Wendy Cadge, and James T. Harrison. 2006. "Religion and Public Opinion about Same-Sex Marriage." Social Science Quarterly 87:340-360. doi: 10.1111/j.1540-6237.2006.00384.x

Pew Research Center. "Millennials in Adulthood: Detached from Institutions, Networked with Friends." in Social and Demographic Trends. Washington, D.C.: Pew Research Center.

—. 2014b. "Religion \& Public Life Project:Changing Attitudes on Gay marriage." vol. 2014: Pew Resarch

—. 2014c. "Religion and Public Life Project." Washington, D.C.: Pew Research Center.

Pond, Allison, Gregory Smith, and Scott Clement. 2010. "Religion Among the Millennials." Pew Research Center, Washington, D.C.

Public Religion Research Institute. 2014. "News Release: American Religious Landscape Transforming as Support for Same-Sex Marriage Dramaticaly Increases." Washington, D.C.: Public Religion Research Institute. Http://publicreligion.org/newsroom/2014/02/2014-lgbt-survey/

Putnam, Robert D. and David E. Campbell. 2010. American Grace: How Religion Divides and Unites Us. New York: Simon \& Schuster.

Rowatt, Wade C., Jordan LaBouff, Megan Johnson, Paul Froese, and Jo-Ann Tsang. 2009. "Associations Among Religiousness, Social Attitudes, and Prejudice in a National Random Sample of American Adults." Psychology of Religion and Spirituality 1:14-24. doi: 10.1037/a0014989

Sherkat, Darren E., Mellisa Powell-Williams, Gregory Maddox, and Kylan Mattias de Vries. 2011. "Religion, Politics, and Support for Same-sex Marriage in the United States, 1988-2008." Social Science Research 40:167-180. doi: 10.1016/j.ssresearch.2010.08.009

Silver, Nate. 2013. "How Opinion on Same-Sex Marriage is Changing, and What it Means." in FiveThirtyEight: Nate Silver's Political Calculus. New York, NY: The New York Times.

Http://fivethirtyeight.blogs.nytimes.com/2013/03/26/how-opinion-onsame-sex-marriage-is-changing-and-what-itmeans/?_php=true\&_type $=$ blogs \&_r $=0$

Skipworth, Sue Ann, Andrew Garner, and Bryan J. Dettrey. 2010. "Limitations of the Contact Hypothesis: Heterogeneity in the Contact Effect on Attitudes toward Gay Rights." Politics and Policy 38:887-906. doi: 10.1111/j.17471346.2010.00262.x

Smidt, Corwin E. 2013. American Evangelicals Today. Lanham, MA: Rowman \& Littlefield Publishers, Inc.

Streensland, Brian, Jerry Z. Park, Mark D. Regnerus, Lynn D. Robinson, W. Bradford Wilcox, and Robert D. Woodberry. 2000. "The Measure of American Religion: Toward Improving the State of the Art." Social Forces 79:291-318. doi: 10.2307/2675572 
Whitehead, Andrew L. 2010. "Sacred Rites and Civil Rights: Religion's Effect on Attitudes Toward Same-Sex Unions and the Perceived Cause of Homosexuality." Social Science Quarterly 91:63-79. doi: 10.1111/j.15406237.2010.00681.x 